\title{
スマート緟光プローブの精留開発による 新たな分子イメージング
}

東京大学大学院医学系研究科

浦 野 泰 照*

New molecular imaging with precisely designed smart fluorescence probes

We succeeded to construct several versatile rational design strategies for novel fluorescence probes. Indeed, based on these design strategies, various novel fluorescence probes were successfully developed including those for reactive oxygen species, reporter enzymes.

Here, I will describe the details of probe design as well as some imaging results with our novel smart probes.

筆者らはこれまでに，新規有機小分子蛍光プローブの効率的な開発を可能とする，論理的かつ汎用 性の高いプローブデザイン法を，世界に先駆けて確立することに成功し，特定の活性酸素種を検出可 能な蛍光プローブ群や, さまざまなレポータ一酵素, 生体関連酵素活性を高感度に検出可能な蛍光プ ローブなどの開発に成功してきた.

本稿では, プローブのデザイン法から, 開発したスマートプローブの活用による種々のイメージン グ例まで幅広く概説する.

Yasuteru Urano*

Key words : fluorescence probe, photoinduced electron transfer, reactive oxygen species, reporter, enzyme, cancer imaging

近年, 生命現象の解析や病態要因の解明などにお いて，“生きている状態の生物試料”における種々の 生理活性物質の動態をリアルタイムに観測すること がきわめて重要であることが, 強く認識されるよう になっている。このような観測を実現する技法とし て, 現在, 観測対象分子を高感度に可視化する蛍光 プローブを用いて, 蛍光顕微鏡下で生細胞応答を観 測する技法が広く汎用されている.

これまでに開発されてきた蛍光プローブは, GFP (green fluorescent protein)などの蛍光蛋白質を ベースとするものと有機合成小分子をべースとする ものに大別される，蛍光蛋白質をべースとするプ ローブは，遺伝子導入によって細胞に発現させるだ けで簡便にイメージングが可能であるという特長を 持ち, キナーゼ活性からカルシウムイオンの動態な ど，さまざまなイベントを可視化するプローブが開 発されてきた。 これらのプローブの作動原理は，主 に二つの蛍光蛋白質間のエネルギー移動 (FRET :

\footnotetext{
* Graduate School of Medicine, The University of Tokyo
}

Förster resonance energy transfer)であり，蛍光波 長の変化を検出することで検出対象分子の存在の可 視化を実現している。 これらのプローブは，遺伝子 でコードされているため, 構成アミノ酸の point mutation によって網羅的にヴァリアントを作成し, 最もよい応答を示すものを探し出すという開発手法 が可能であることも大きな利点である.

一方で, trial and error 式の開発しかできないた め, 検出対象分子のレパートリーはそれほど広くな い点が問題であり, その他, 細胞内のプローブ発現 量を制御することが難しい点, 蛍光蛋白質中の蛍光 団の生成に時間がかかる点，また蛍光スペクトルの 幅が広く多色検出が困難である点などが問題点とし てよくあげられている。

一方で，有機小分子をベースとするプローブは, 細胞外液に添加するだけですべての細胞に，速やか にかつ濃度を制御して導入可能であるなどの特長を 有するため, 多種多様なプローブの開発が強く望ま れている.

本プローブ群の検出原理としては, FRETよりも 
むしろ蛍光消光 (quenching)がよく用いられてい る. すなわち, それ自身は何らかの消光過程の存在 により無蛍光であるが, これが観測対象分子と反応, 結合することで強い蛍光を発するようになる蛍光プ ローブ分子が数多く開発されてきた.

図1aに，このような合成小分子蛍光プローブを 用いて，“生きている”細胞を“生きたまま”観測す る手法の原理を簡潔にまとめた．観測対象とする生 理活性分子 $(\nabla)$ の検出を考えるとき，ほとんどの生 理活性物質は無色であるため, 光学顕微鏡でただ観 察してもその動きを知ることは出来ないが， マと反 応・結合することではじめて蛍光を発する合成小分 子蛍光プローブを細胞内に存在させることで， $\nabla$ の 動きを蛍光の変化として, 高感度かつリアルタイム に追うことが可能となる.

たとえば， $\mathrm{Ca}^{2+}$ イオンが細胞内の情報伝達を司る 代表的なセカンドメッセンジャーとして働いている ことは，すでに疑いのない事実であるが，これは $\mathrm{Ca}^{2+}$ イオンを選択的に蛍光検出可能な蛍光プロー ブの開発によるところがきわめて大きい. 代表的な $\mathrm{Ca}^{2+}$ イオン検出蛍光プローブである fluo-3 の構造 と $\mathrm{Ca}^{2+}$ イオン検出の原理を図 1b に示した. Fluo-3 は, フルオレセイン骨格と $\mathrm{Ca}^{2+}$ イオンキレーター である BAPTA 部位とが融合した構造であるが, $\mathrm{Ca}^{2+}$ フリーの状態ではほぼ無蛍光であり，これが $\mathrm{Ca}^{2+}$ イオンと結合することでその蛍光強度が 36〜 40 倍に上昇するため, $\mathrm{Ca}^{2+}$ イオン検出蛍光プロー ブとして機能する11.

\section{分子内光誘起電子移動に基づく蛍光プローブ の論理的精密設計法の確立}

上述のように，生細胞観測にきわめて重要な役割 を果たす蛍光プローブであるが，これまでに開発さ れてきた有機小分子蛍光プローブのほとんどは trial and error 方式で開発されてきており, 望みの機 能を実現する蛍光プローブを狙って開発することは きわめて困難であった。この理由として, 現代の最 新の量子化学計算を駆使しても, 新たな有機化合物 の蛍光特性, なかでもその明るさ (蛍光量子収率)を 正確に予測することはほぼ不可能であり，それら新

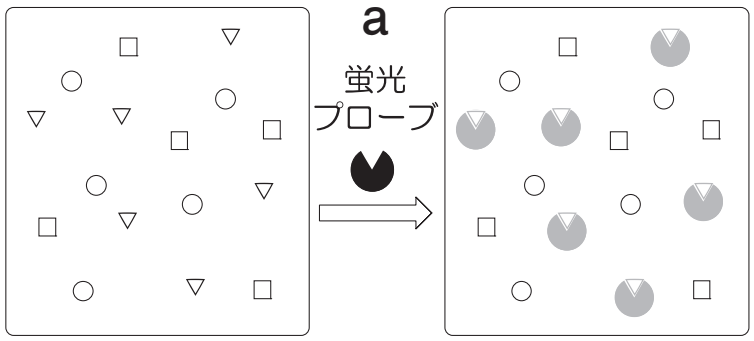

蛍光プローブとは、

·観測対象分子と「特異的に」反応·結合し

.その前後で蛍光特性が大きく変化する

機能性分子である.（上図は細胞を模式的に表したもの

จの分子のみを特異的に検出する）

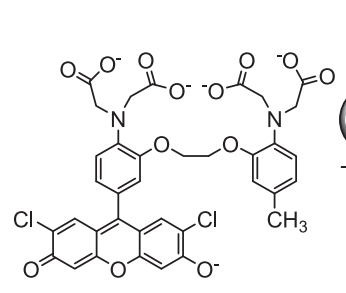

Fluo-3 (ほぼ無蛍光) $\left(\Phi_{\mathrm{fl}}=0.005\right)$

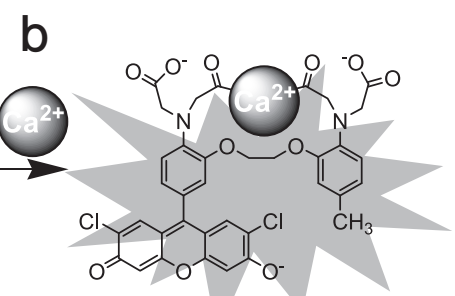

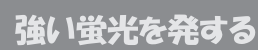

$\left(\Phi_{\mathrm{fl}}=0.183\right)$
図 1

$\mathrm{a}$ : 蛍光プローブの機能. $\mathrm{b}$ : 代表的な $\mathrm{Ca}^{2+}$ イオン検出蛍光プ ローブ fluo-3 の, $\mathrm{Ca}^{2+}$ イオン結合前後における蛍光特性変化

規物質を実際に合成し，蛍光特性を実測してみるま で，光るか光らないかはわからないことがあげられ る.

よってこれまで，もともとは無蛍光性であり， と反応・結合することではじめて蛍光を発する蛍光 プローブを開発するには，試行錯誤に基づくことが 一番の近道であったが, この方法では新たな検出対 象分子を可視化する蛍光プローブを開発できる保証 はまったくなく，実際これまでに開発されてきた蛍 光プローブのターゲットは, 各種典型金属イオンな ど非常に限られたものであった。

そこで筆者らは，このような状況を打破し，目的 の機能を有する蛍光プローブを論理的に精密に設計 することを目標とした研究を行ってきた結果, 光誘 起電子移動 (photoinduced electron transfer : PeT) を設計原理とする蛍光プローブの論理的なデザイン 法を確立することに成功した.

すなわち，たとえば代表的な蛍光分子であるフル オレセインは，分子をベンゼン環部位と蛍光団であ るキサンテン環部位の 2 部位に分けて考えることが 可能であり, 分子内 PeTによりその蛍光特性を精 


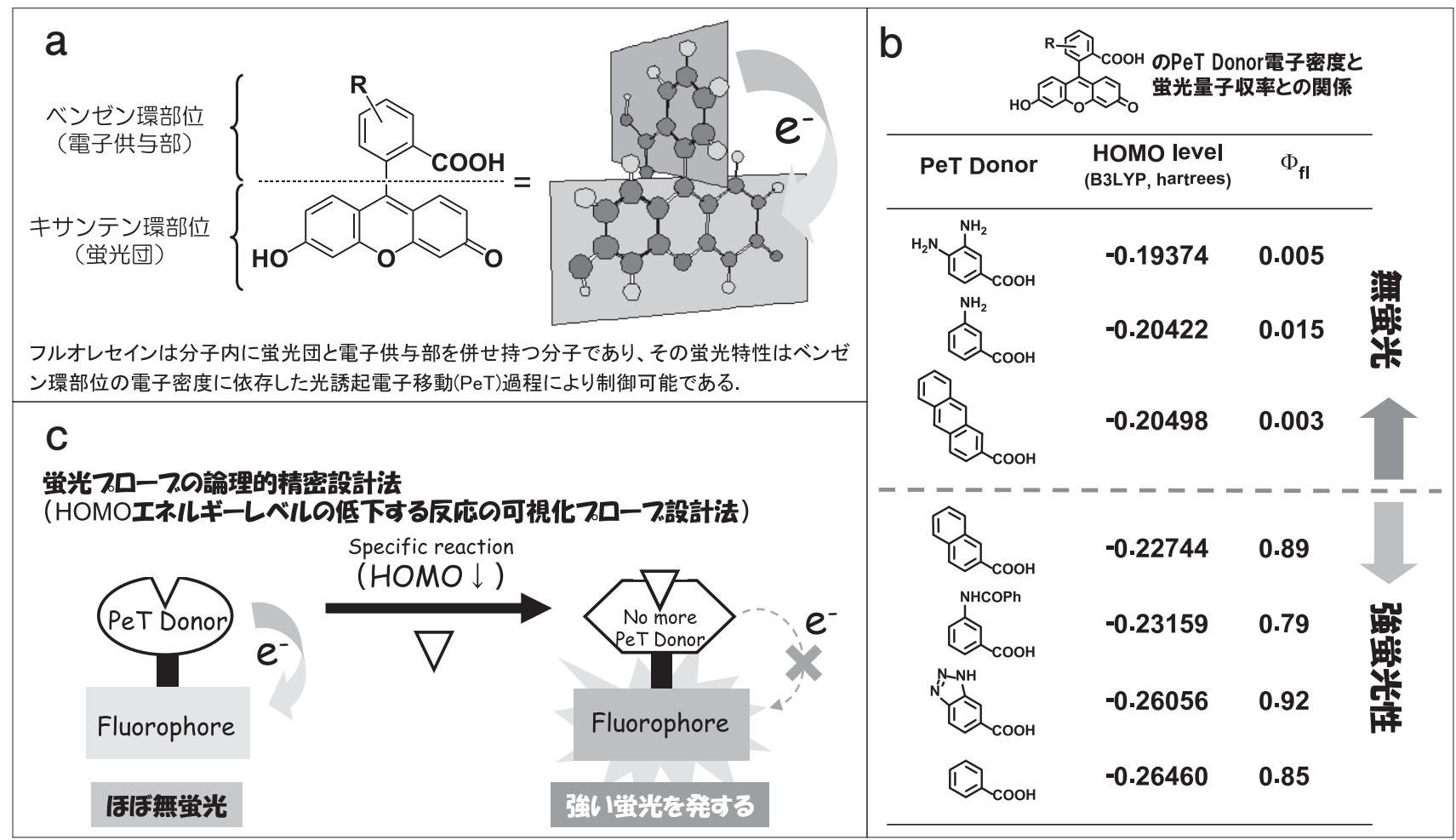

図 2 分子内光誘起電子移動に基づく蛍光プローブの論理的設計法の確立

$\mathrm{a}$ ：代表的な長波長励起蛍光分子であるフルオレセインは二つの部位に分割して考えることができる.

b : フルオレセイン誘導体の蛍光量子収率は, ベンゼン環部位の HOMO エネルギーレベルに依存した

光誘起電子移動の概念によって，精密に予測することが可能である.

c ：これまでに確立した, 光誘起電子移動に基づく蛍光プローブの論理的精密設計法の一例

密に制御可能であることを見出した(図 2a).

具体的には, ベンゼン環部位の HOMO エネル ギーレベルがある值よりも高いフルオレセイン誘導 体はすべてほぼ無蛍光であり，これが低い誘導体は 全てフルオレセインと同等の強い蛍光を発すること が明らかとなった (図 $\mathbf{2 b})^{2,3)}$.

なぜ一般に，予測不可能であった蛍光特性を，筆 者らの手法を用いた分子設計では予測可能となった かを簡単に述べるならば，筆者らの手法では蛍光団 であるキサンテン環にはまったく修飾を加えておら ず，蛍光団とは $\pi$ 電子共役していないベンゼン環部 位に修飾を加えているため，蛍光団自身の基本的な 特性は損なわれていないことがあげられる.

実際, この手法に基づく分子設計では, その吸収・ 蛍光スペクトルはほとんど変化せず，量子収率のみ が変化するなど, 蛍光団自身の基本的な特性は保た れていることが明らかとなっている.

以上の知見を発展させることで，筆者らは，図 2c
に示した蛍光プローブの論理的設計法の確立に成功 した，すなわち，ある観測対象分子に対する蛍光プ ローブの開発を考える際，その観測対象分子と特異 的に結合・反応し，かつその反応前後で基質の HOMO エネルギーレベルが大きく低下する化学反 応 (分光学的な变化は一切必要ない)さえ知っていれ ば，これを活用して反応前は PeTによりほぼ無蛍 光であり, 反応後に PeT が起こらなくなることで 強い蛍光を発するプローブを論理的に開発すること が可能となった.

各種活性酸素種 (ROS)，および関連酵素活性の選 択的検出を可能とする蛍光プローブの論理的開発

活性酸素種 $(\mathrm{ROS})$ は，炎症，がんなど多くの疾患 に関わるとされ，また近年では細胞内情報伝達物質 としての役割も持つとの指摘もあり，ますます注目 を集めている。一口にROSといっても，スーパー 
オキシド, 過酸化水素, 八イドロキシルラジカル, 一重項酸素など多くの種が存在し，これらはそれぞ れ特徵的な化学反応性を持つことから, 生体内にお いても異なる役割を持つ可能性も高い.

$\mathrm{ROS}$ 検出用蛍光プローブは, 筆者らの研究以前 にもいくつか開発され，なかでもジクロロフルオレ セインの 2 電子還元体である DCFH (dichlorodihydrofluorescein)が広く用いられてきた。しかしなが ら，DCFH には ROS 間の特異性はまったくなく, また励起光を当てるだけで ROS の有無にかかわら ず大きく蛍光が増大してしまう欠点を持っており， 生物学的に意味あるデー夕を得ることは困難であっ た。

そこで筆者らは，上述の蛍光プローブデザイン法 を活用し, ある特定の活性酸素種のみを検出可能な 蛍光プローブの精密設計を試みた結果, 多数の新規 蛍光プローブの開発に成功した ${ }^{4-7)}$ 。たとえば一重 項酸素(図 3a) とパーオキシナイトライト(図 3c) と をそれぞれ高選択的かつ高感度に検出可能な蛍光プ ローブは, 前者はアントラセンからエンドパーオキ

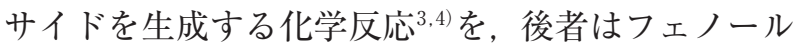
のニトロ化反応 ${ }^{6}$ をそれぞれ鍵化学反応として活用 することで，論理的にそれぞれの蛍光プローブを開 発することに成功した。

さらに，好中球に含まれるミエロパーオキシダー ゼによって産生される ROSであり, 高い活性を有 する hROS の一種である次亜塩素酸を特異的に検 出可能な蛍光プローブ HySOx の開発にも成功し た ${ }^{7)}$ そそのプローブ設計原理は，これまで紹介して きたPeT とは異なり，ローダミン骨格の分子内閉 環・開環平衡の制御に基づくものであり, HySOx プ ローブ自身は色も蛍光も持たない化合物であるが, これが次亜塩素酸イオンと反応すると通常のローダ ミン蛍光を発する生成物へと変化する(図 3d).

本プローブは，抗光褪色性のローダミンをその母 核とするものであるため, 同一視野の連続観察時に おけるプローブの褪色がまったく見られないなど, きわめて生細胞イメージングに適した性質を持つ. 実際，ブタ好中球によるザイモザン貪食時に生成す る次亜塩素酸のリアルタイム連続観測を試みたとこ ろ，ザイモザンを食食して生成したファゴソーム内
のみに, 貪食のタイミングときわめてよく相関して, 強いローダミン蛍光が生成することが観測された.

本結果は，好中球の活性化による次亜塩素酸生成 をリアルタイムで可視化したはじめての例であり， 白血球の生理作用解析や, 医薬品開発に大きな力を 発揮するものと期待している。

TokyoGreen 骨格の創製に基づく，各種加水 分解酵素・反応可視化蛍光プローブの開発

さらに筆者らは, フルオレセインの骨格構造を $\mathrm{PeT}$ の観点から見直すことで, 新たな蛍光プローブ デザイン法に繋がる誘導体群の創製に成功した。す なわち, 上記の PeT の考え方によれば, カルボキシ 基は他の官能基に変換することが可能なはずである と考え，メチル基，メトキシ基など他の官能基に置 換した誘導体の開発に成功した(図 4a)。驚いたこ とに，これらの単純なフルオレセイン誘導体は新規 化合物であり，また以下に詳述するようにこれらは きわめて有用な蛍光プローブ母核となるものであっ たため,これらの新規蛍光骨格を TokyoGreen(以 下 TG) と命名した8).

つぎに, これら TGs の蛍光特性を精査した結果, ベンゼン環 $\mathrm{HOMO}$ エネルギーレベルの上昇により 蛍光量子収率が減少するという PeT の原理に一致 した結果が得られたばかりでなく，蛍光 On/Off の 境界はキサンテン環部位の水酸基がアニオン型であ る場合と，分子型である場合で大きく異なることも 明らかとなった (図 4b). 本知見はプローブ設計の 観点から非常に有用である.

すなわち, 図 4b のオレンジの枠で囲った m-メト キシトルエンをベンゼン環部位として持つ TG は, キサンテン部位がアニオン型の時は強蛍光性である 一方，分子型になるとほぼ無蛍光であるという特異 な性質を有するキサンテン系色素といえ，きわめて 有用な蛍光プローブ母核となり得ることを示してい る.

以下，本特性を活用して開発に成功した各種加水 分解酵素・反応可視化蛍光プローブを紹介する.

まず, $\beta$-ガラクトシダーゼ活性検出蛍光プローブ TG- $\beta$ Gal(図 4c) を紹介する. 


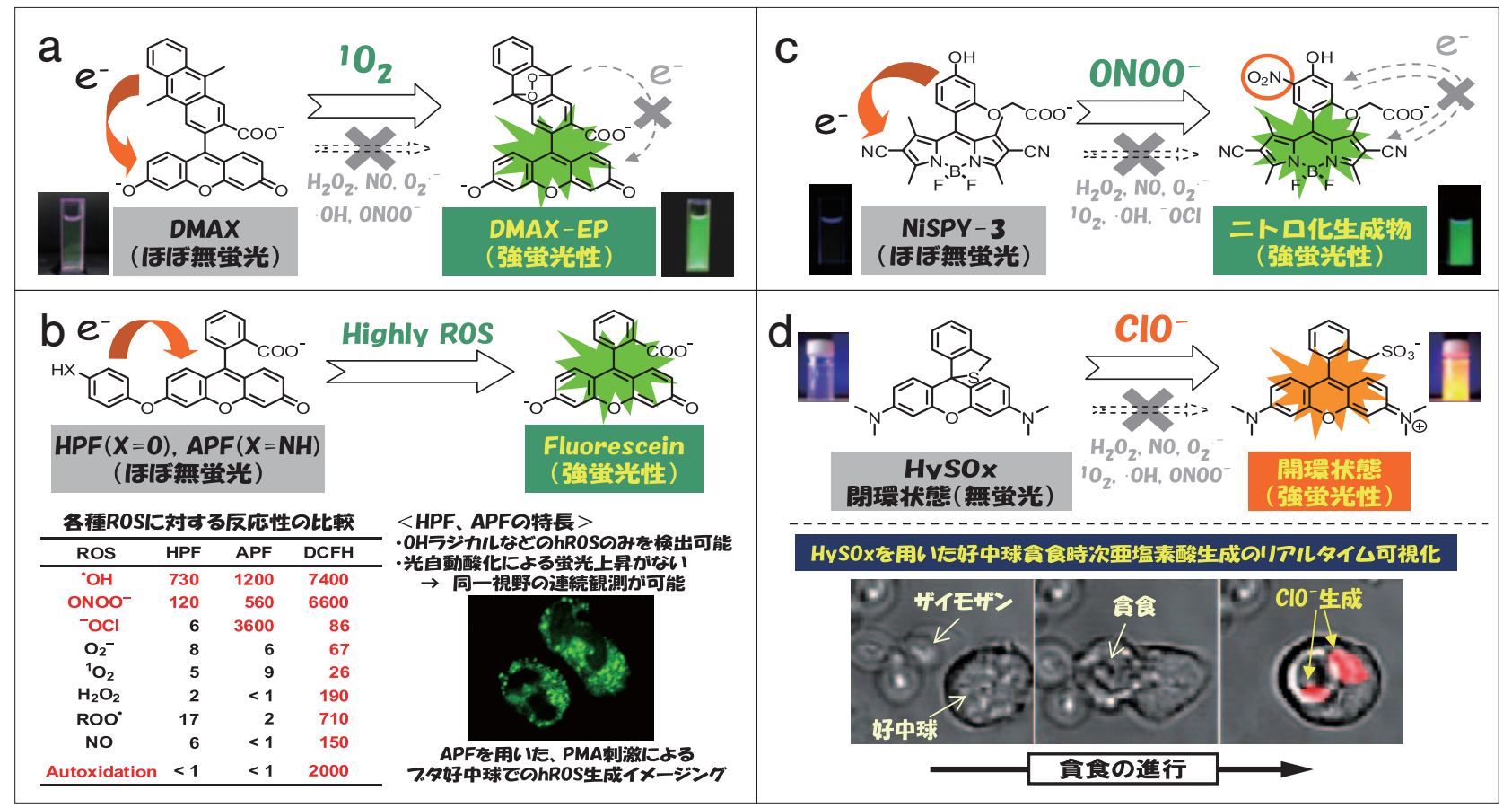

図 3 確立した設計法に基づき開発に成功した，各種活性酸素種を種特異的に検出可能な蛍光プローブ群 $\mathrm{a}$ ：一重項酸素検出蛍光プローブ DPAX, DMAX 類. b : 強い酸化活性種(hROS)のみを検出するプローブ HPF, APF c : ニトロ化ストレス検出蛍光プローブ NiSPY 類. d : 次亜塩素酸特異的, 抗光裉色性蛍光プローブ HySOx
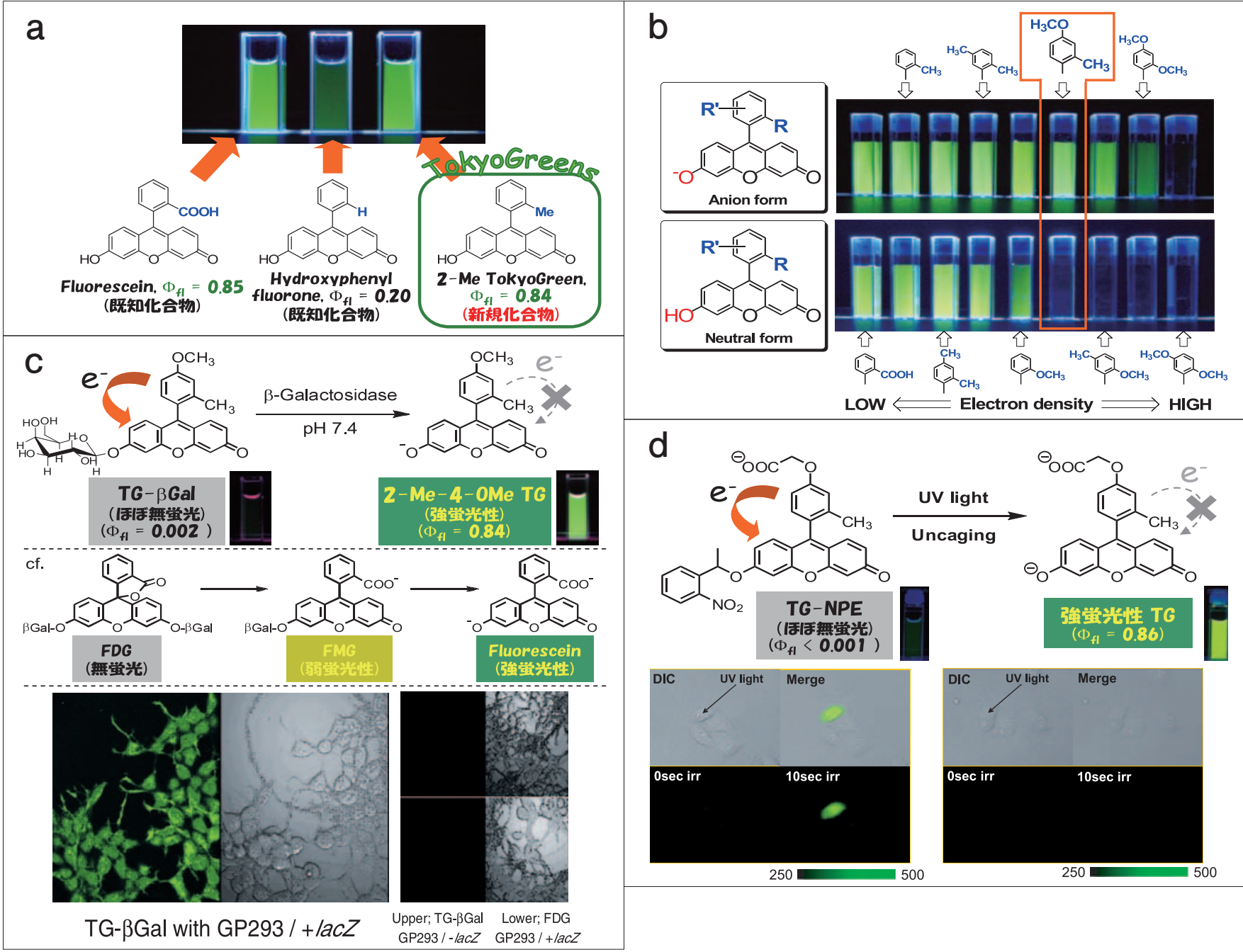

図 4 新規蛍光骨格 TokyoGreen 類の創製とこれに基づく各種蛍光プローブの開発 


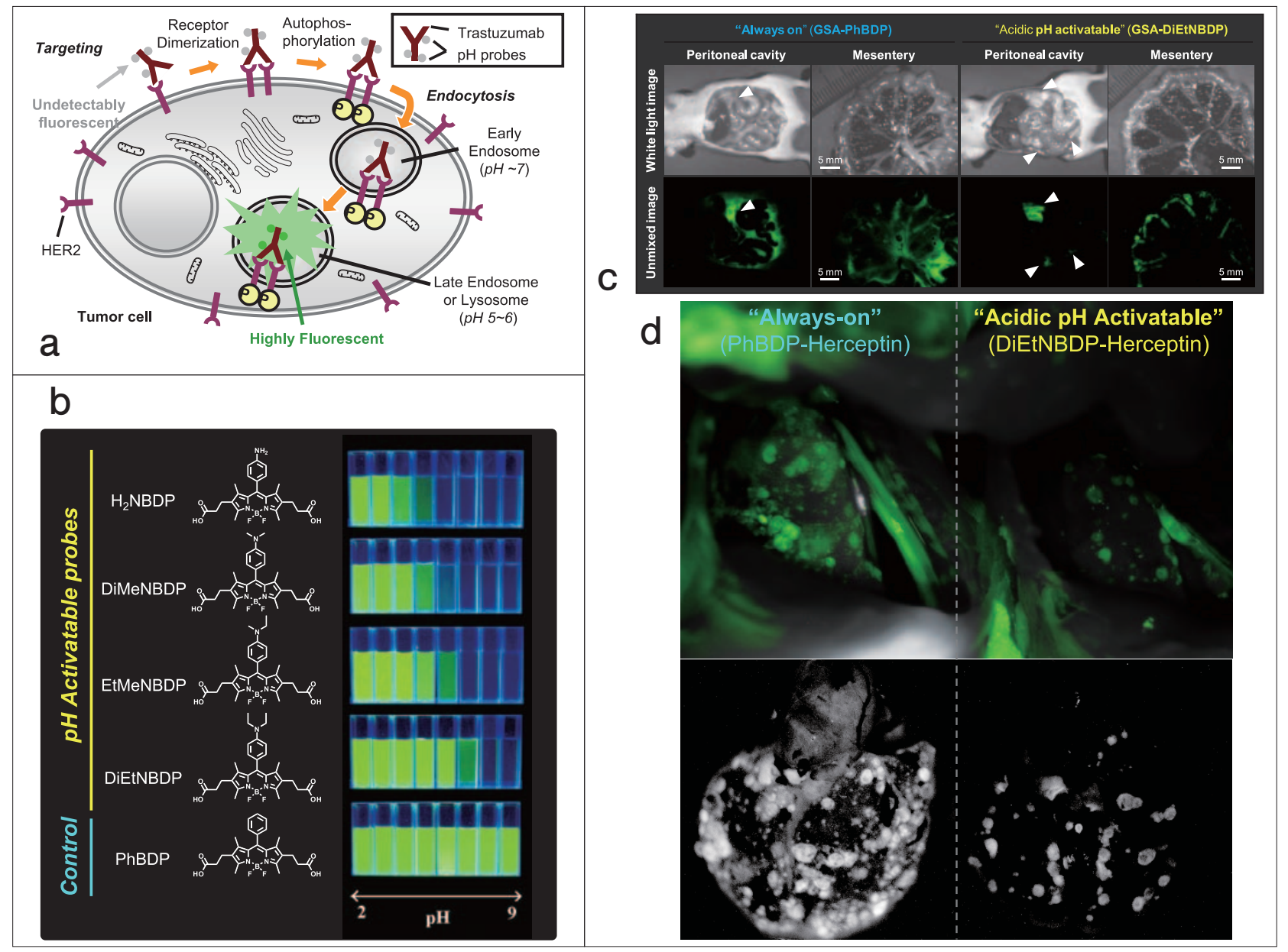

図 5 高選択的 in vivo 蛍光がんイメージングの実現

$\mathrm{a}$ ：がん抗体や各種夕ンパク質のがん細胞特異的なエンドサイトーシスと, エンドソームが最終的にライソソーム

へと運搬されることを活用した, 高選択的がんイメージング戦略

b : 弱酸性環境ではじめて蛍光を持つ新規蛍光プローブ群の開発

$\mathrm{c}$ ：腹腔播種がんモデルマウスへの腹腔内投与による高選択的がんイメージング

d：肺がんモデルマウスへの静脈注射による高選択的がんイメージング

TG- $\beta \mathrm{Gal}$ は， m-メトキシトルエンをそのベンゼ ン環部位とする TG 類であり, このプローブ自身の キサンテン環部位の水酸基は，ガラクトースと結合 しているエーテル構造となっており, よって pH 7.4 の水溶液中でも分子型をとる結果, ほぼ無蛍光 性である。これが $\beta$-ガラクトシダーゼにより特異 的に加水分解されることで，キサンテン環部位の水 酸基はフリーとなるが，その $\mathrm{pKa}$ が約 6.2 である ため脱プロトン化してアニオン型となるため, 生成 物である 2-OMe-4-Me TG は強い蛍光を発する.

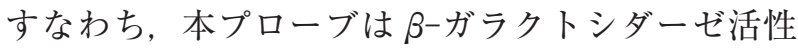
検出蛍光プローブとして機能する。実際，本反応前 後での蛍光増大率は約 800 倍にも達し, きわめて鋭 敏に $\beta$-ガラクトシダーゼ活性検出が可能である.

$\beta$-ガラクトシダーゼは，レポーター酵素として最
も汎用されているが, これまでの検出法は X-Gal 染 色などの吸光法を原理とするものがほとんどであ り，原理的に高感度であるはずの蛍光法が用いられ ることは非常に少なかった。今回，開発に成功した TG- $\beta \mathrm{Gal}$ は分子内に糖部位を一つしか持たず，これ が加水分解される 1 段階の反応で, 従来から知られ ている蛍光プローブ(fluorescein-di- $\beta$-galactoside : FDG，図 4c)の 2 段階分に相当する最大の蛍光強度 変化を生じるように設計されているため, 非常に感 度良く $\beta$-ガラクトシダーゼ活性を検出することが 可能となった。本プローブは生細胞系への適用が可 能であり, 実際図 4c に示したように, 生細胞系にお

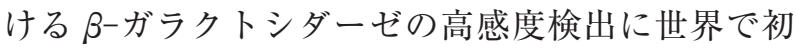
めて成功した8,9).

上述の設計法で用いるアルキル基部位は，もちろ 
んガラクトースに限られるものではない.これを光 解除性保護基であるニトロベンジル基とすれば，い わゆる caged 蛍光色素が誕生する。実際, 本設計法 に基づて開発された TG-NPE は，それ自身は分 子内 PeT の結果ほほ無蛍光であり, ここに $350 \mathrm{~nm}$ の解除光を照射することで大きな蛍光増大を示す caged 蛍光色素として機能する. TG-NPE は上述の $\mathrm{TG}-\beta \mathrm{Gal}$ と同様, 1 段階の光解除性保護基の脱離に より最大の蛍光強度変化を生じるため, 従来色素に くらべきわめて短時間の解除光照射で単一細胞の蛍 光染色が可能であることも示された (図 4d ${ }^{10)}$.

\section{蛍光イメージングプローブの精密設計に基づ くがん選択的光イメージング}

臨床的な観点からがんは, 発見時の進行度により 患者の予後が大きく左右されることが一般的に知ら れており, 実際胃がん, 肺がん, 結腸がん, 乳がん など主要部位のがんにおいて，がんの早期発見の重 要性が示されている.

従来, がん診断には, PET, SPECT, MRI，およ びUS 技法などが用いられてきたが，これらの技法 で得られる画像は, 簡潔にいえばプローブの集積度 の画像である。すなわち，がん集積性の高いプロー ブが，がんに集積する性質を利用して，がんの画像 化を実現するものである，しかし，全プローブ分子 ががんのみに集積するわけではなく，代謝，排泄に 関わる臓器である肝臓や腎臓への集積や, 非特異的 に正常部位へと吸着・分布するプローブも多い.よっ て全身スキャン時にはこれが大きなバックグラウン ドシグナルとして画像化されてしまい, 結果として 小さながん部位を見逃してしまう可能性がかなり高 い(図 6a).

また，たとえば FDG-PET は，がん細胞が異常に 高い代謝活性を持ち，活動のエネルギーである糖を 多く取り込むことを利用したプローブであるため, 同様に糖を大量に取り込む臓器である脳や心臓, ま た細胞活動性の高い炎症部位も強いシグナルを発す るなど,がん特異性の問題も依然として残っている.

上述の臨床画像取得技法と比較して, 光を検出原 理とする技法は, 光の組織透過性の問題から第一選
択の技法としては敬遠されてきた。しかしながら筆 者は，蛍光を原理とする分子イメージングに基づく 画像取得技法は，従来の技法では実現不可能ながん 部位と正常部位の質的な差異を見分けて，これを画 像化することが可能であり, 高感度かつ高選択的な がんイメージングが可能となるのではと考えた(図 6b). もちろんこのようながん部位特異的な蛍光イ メージングを実現するためには，がん部位を見分け てその蛍光特性が大きく変化する蛍光プローブの精 密設計・開発が必須となる.

一般に，動物個体におけるin vivo がんイメージ ングを考える場合，有機小分子である蛍光プローブ 単体の体内動態を精密に制御し，高いがん選択性を 付与することはほぼ不可能である。 そこで筆者は, 米国国立衛生研究所の小林久隆先生と協同して, 有 機小分子プローブ単体ではなく，がん選択的に取り 込まれる抗体とこれががん細胞に取り込まれたこと を検知する機能を持つ有機小分子プローブと組み合 わせる戦略で, 高選択的 in vivo がんイメージング の実現を図った ${ }^{11)}$. 以下，その概略を紹介する.

がん細胞に選択的に取り达まれる抗体は，現在で は抗体医薬として治療に用いられているなど，すで に数多く開発されている。 これら抗体の細胞への取 り込みは, 細胞表面抗原への結合をトリガーとする エンドサイトーシス経路で起こり, 抗体は最終的に 細胞内オルガネラの一つであるリソソームへと運搬 される。すすなわ，細胞内リソソームの特徵的な環 境を認識してはじめて蛍光性となる蛍光プローブを 開発し，これをがん特異的抗体に結合させたプロー ブ複合体を作成すれば, 高選択的 in vivo がんイメー ジングを実現できるものと考えた(図 5a).

具体的には, リソソーム内は通常の細胞内・外の 環境と異なり弱酸性であることに着目し, 中性条件 下では蛍光を持たず，弱酸性環境を検知してはじめ て光る蛍光プローブの開発を行った。すなわち，ア ニリン部位を酸性環境認識部位, BODIPYを蛍光団 とし，アニリン部位がプロトネーションされていな いときは分子内 PeTにより消光し, 酸性環境下で プロトン化されると高蛍光性へと変化するプローブ を設計，開発した。ささらに，アニリン部位として各 種アルキル置換基をアミノ基上に導入することで, 


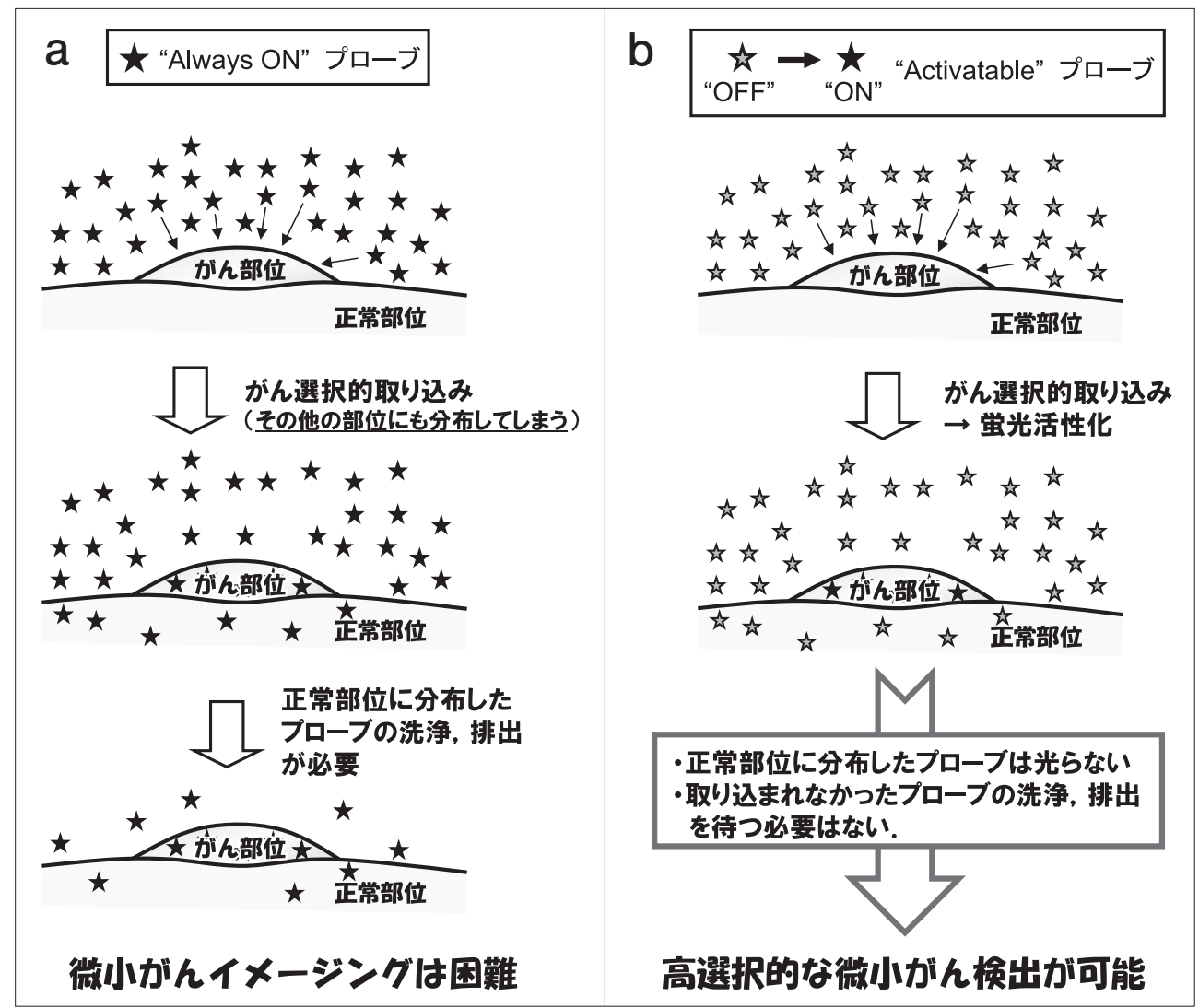

図 6 従来のがん診断技法と, 筆者らが今回開発することに成功した蛍光を活用した高選択 的がんイメージング手法

a : PET, MRI などの“Always ON”プローブによるがんイメージング法

b : 今回確立した“Activatable” 蛍光プローブの精密設計による微小がんイメージング手法

$\mathrm{pKa}($ 蛍光・無蛍光の境目となる $\mathrm{pH})$ の異なる一連 の弱酸性環境検出蛍光プローブ群の開発にも成功し た(図 5b). そこでこれらの小分子蛍光プローブを, 代表的ながん特異的抗体である herceptin へと共有 結合させ，がんイメージングプローブ複合体を作成 した。

つぎに，開発したプローブ複合体を, herceptin を取り込むことが知られている HER2(上皮成長因 子受容体の一つ．乳がんなどで充進していることが 知られている)を発現している培養細胞系へと適用 した。まず，コントロールとして, pH に関係なく常 に強い蛍光を発する蛍光団を結合させた抗体(以下 Always ON と表記)を細胞外に加えると, 加えた直 後から細胞膜上に強い蛍光が観察された。これは herceptin が HER2 受容体に結合していることを示 している. 2 時間ほどたつと, 細胞内にもエンドソー ム, ライソソームに由来するドット状の明るい蛍光
が観測された.

本結果は, Always ON プローブでは, がん細胞に 取り込まれずに残る薬剤によるバックグラウンド蛍 光がきわめて強いことを示すものであり，このよう な単純な蛍光団-抗体の複合体ではがん部位選択的 な検出は不可能であることを示すものである.

一方, 弱酸性環境下ではじめて蛍光を発するプ ローブを結合させた抗体 (以下 “pH-activatable” と 表記)を適用した系では，プローブ添加直後はまっ たく蛍光が観察されなかった，本系でも， herceptin と HER2 は Always ON プローブの場合と同じ く強く結合しているはずであるが，プローブは pH7.4の細胞外に存在するため, 細胞膜上には蛍光 が観測されなかったと考えられる。 その後, プロー ブはエンドサイトーシスによって徐々に細胞内へと 取り込まれ，リソソーム内へと運搬され，2 時間ほ どすると細胞内にのみ明るいドット状の蛍光が観察 
されはじめた。これは 24 時間以上持続し, 最終的に はかなり明るい蛍光を発するようになった。

以上の結果は，がん細胞に取り込まれることでは じめて蛍光を発するという, 当初期待した通りの機 能を有することを端的に示すものである(図 5c).

そこでつぎに, HER2 陽性がん細胞を肺に転移さ せたがんモデルマウスに，静脈内注射によりプロー ブを投与し，1 日後に開腹して肺の蛍光スペクトル イメージングを行った。 その結果, Always ON プ ローブを投与したマウスでは,がん部位だけでなく， 筋肉組織や血中など，体内の至るところが蛍光を発 しており, 微小がんのイメージングは不可能であっ たのに対して, 弱酸性環境下ではじめて光る $\mathrm{pH}-$ Activatable 蛍光プローブを結合させた抗体を投与 したマウスでは, がん部位のみが高選択的に蛍光を 発しており，バックグラウンド蛍光はきわめて低い レベルに抑えられることが明らかとなった（図 5d).

つぎに，心臓と肺を体外に取り出して ex vivo イ メージングを行ったところ, Always ON プローブ を投与したマウスではがん部位のみでなく, 肺の表 面や心臓からも蛍光が観測されたのに対して, 弱酸 性環境検出 $\mathrm{pH}$-activatable プローブを投与したマ ウスでは，がん部位のみが強い蛍光を発しており，

$1 \mathrm{~mm}$ 以下のごく微小ながんであっても，これを高 感度・高選択的に蛍光イメージング可能であること が明らかとなった(図 5d).

さらに，腹腔播種がんモデルマウスへと本設計指 針と同様のプローブを適用し, 生きているマウス中 にできている微小がんを，蛍光内視鏡を使うことで 可視化することにも成功し，本手法が実際のがん診 断, 手術に直結する技術であることも確かめられた.

具体的な動画などは，参考論文 ${ }^{11)}$ を参照していた だければ幸いである。

\section{おわりに}

筆者らが最近確立することに成功した有機小分子 蛍光プローブの論理的な設計法により, 開発可能な 蛍光プローブの種類は飛躍的に増大し, 実際, 本稿
で紹介してきたように, 生きている生物試料の中で 起こる各種イベントを可視化する新規蛍光プローブ 群の開発に成功した.

開発した蛍光プローブ群は, 細胞培養液に添加す るだけで，容易に細胞膜を通過して生きている細胞 に負荷することが可能であり, すぐにでも生物学領 域研究に適用可能な実用性を持っている。 また, 従 来培養細胞系が主な対象であった蛍光プローブ技術 を, in vivo 用のプローブを精緻に設計・開発するこ とで, きわめて高精細なin vivo がんイメージング へと適用拡大することが可能であることを明確に示 すことにも成功した.

確立に成功したがんイメージング技術は，遺伝子 操作を一切用いていないため, その安全性が高い点 も大きな特長であり, 患者さんに手術前日に上述の プローブ類を少量投与するだけで，術者が治療すべ きがん部位を明確に判断でき, 的確な蛍光内視鏡下 手術，あるいは開腹外科手術時が可能となる日も近 いと大いに期待している.

本稿で紹介したがんの蛍光イメージング研究は, 米国 NIH/NCI の小林久隆主任研究員との共同研究 であり，小林先生のアイディアなくしては達成でき なかった成果ばかりである。また，がんイメージン グプローブの開発は, 当研究室助教の神谷真子博士 と東京大学大学院医学系研究科助教の浅沼大祐博士 とともに遂行してきたものである。この場をお借り して，以上のみなさまに深謝いたします。

\section{文 献}

1) Minta A et al. : J Biol Chem $264: 8171-8178,1989$.

2) Miura $T$ et al. : J Am Chem Soc $125: 8666-8671,2003$.

3) Tanaka K et al. : J Am Chem Soc $123: 2530-2536,2001$.

4) Umezawa $\mathrm{N}$ et al. : Angew Chem Int Ed $38: 2899-2901$, 1999.

5) Setsukinai K et al. : J Biol Chem $278:$ 3170-3175, 2003.

6) Ueno $\mathrm{T}$ et al. : J Am Chem Soc 128: 10640-10641, 2006.

7) Kenmoku S, et al. : J Am Chem Soc 129: 7313-7318, 2007.

8) Urano Y et al. : J Am Chem Soc $127: 4888-4894,2005$.

9) Kamiya M et al. : J Am Chem Soc 129:3918-3929, 2007.

10) Kobayashi $\mathrm{T}$ et al. : J Am Chem Soc 129:6696-6697, 2007.

11) Urano $Y$ et al. : Nat Med $15: 104-109,2009$. 